\title{
DNA SEQUENCE POLYMORPHISMS IN THE GENUS SACCHAROMYCES. V. CLONING AND CHARACTERIZATION OF A LEU2 GENE FROM S. CARLSBERGENSIS
}

by

\author{
GREGORY PAUL CASEY ${ }^{1,2)}$ and MOGENS BOHL PEDERSEN ${ }^{3)}$
}

1) Department of Physiology, Carlsberg Laboratory Gamle Carlsberg Vej 10, DK-2500 Copenhagen Valby

2) Present address: Anheuser-Busch Companies, Corporate $R+D$, One Busch Place, St. Louis, Missouri 63118-1852, USA

3) Department of Brewing Chemistry, Carlsberg Research Laboratory Gamle Carlsberg Vej 10, DK-2500 Copenhagen Valby

Keywords: S. bayanus, S. cerevisiae, S. monacensis, S. uvarum, bottom fermenting yeast, non-radioactive probes, sulfonated probes, electrophoretic karyotype, OFAGE, FIGE

Saccharomyces carlsbergensis strains used in the production of lager beer are structurally heterozygous in most genetic loci studied to date.

Previous studies have shown that the genotype of lager yeast contains two types of genomes, one of which is derived from $S$. cerevisiae and the other reveals similarities to the genomes of $S$. bayanus and $S$. monacensis. Genes of homeologous chromosomes can be distinguished by characteristic restriction fragment patterns. This is true also for the $L E U 2$ genes which encode the $\beta$-isopropylmalate dehydrogenase and are located on chromosomes III.

In the present work a $L E U 2$ gene from S. carlsbergensis has been cloned and characterized. The cloned $2.6 \mathrm{~kb}$ LEU2 region complements the $\mathrm{S}$. cerevisiae leu2-3 leu2-112 double mutation. The restriction endonuclease site map of the isolated $\mathrm{S}$. carlsbergensis $L E U 2$ gene is different from that of the $\mathrm{S}$. cerevisiae $L E U 2$ gene. Electrophoretic chromosome separation, as well as karI mediated transfer of single chromosomes into $\mathrm{S}$. cerevisiae strains, has shown that the $\mathrm{S}$. carlsbergensis specific $L E U 2$ gene is located on a chromosome III which carries the carlsbergensis specific HIS4 gene. The cloned LEU2 gene shows preferential molecular hybridization to one of the two LEU2 structural alleles present in lager strains, an allele which is also present in type strains of $\mathrm{S}$. bayanus, S. carlsbergensis, $\mathrm{S}$. monacensis and $\mathrm{S}$. uvarum.

\section{INTRODUCTION}

Previous genetic and molecular studies of chromosomes III $(13,18,23), \mathrm{V}(19), \mathrm{X}(7,8)$, XII and XIII (25) in lager brewing strains have revealed the presence of at least two homoeo- logues of each of these chromosomes. These findings have led to the conclusion that the $S$. carlsbergensis lager yeast is an amphiploid consisting of two or more genomes of which one seems to be derived from a $S$. cerevisiae strain

Abbreviations: FIGE = field inversion gel electrophoresis; OFAGE = orthogonal field alternation gel electrophoresis; $\mathrm{SSC}=150 \mathrm{~mm}-\mathrm{NaCl}, 15 \mathrm{~mm}-\mathrm{Na}$ citrate; TBE $=89 \mathrm{~mm}$-Tris-borate, $89 \mathrm{~mm}$-boric acid, $2 \mathrm{~mm}$-EDTA. 
while the other shows homology to $\mathrm{S}$. bayanus and $\mathrm{S}$. monacensis strains. Homoeologous genes in the two genomes are distinguishable by their restriction endonuclease fragment patterns. This is also true for the LEU2 genes, located on chromosomes III, encoding the $\beta$-isopropylmalate dehydrogenase $(1,2,9,11,23)$. The two $L E U 2$ genes in lager yeast strains can be identified by their Sall diagnostic restriction fragment patterns (23). Pattern III for the S. cerevisiae-like $L E U 2$ is characterized by the presence of a $16 \mathrm{~kb}$ Sall fragment and pattern IV for the $\mathrm{S}$. bayanus and S. monacensis-like $L E U 2$ by the presence of a $12 \mathrm{~kb}$ Sall fragment.

In chromosome III addition and substitution strains the $L E U 2$ allele, characterized by the Sall fragment IV, co-segregates with the HIS4 allele displaying the restriction fragment pattern II $(13,18,23)$. While the $L E U 2$ allele associated with Sall fragment III is present in industrial S. carlsbergensis and S. cerevisiae strains (15, 22, 23 ), the LEU2 allele associated with SalI fragment IV has, until now, only been detected in S. carlsbergensis lager brewing strains, $\mathrm{S}$. monacensis, S. bayanus and S. uvarum $(22,23,24)$.

In the present investigation we describe a 2.6 $\mathrm{kb}$ DNA fragment cloned from a genomic library derived of the S. carlsbergensis lager production strain 244 . The fragment is (i) able to complement an $\mathrm{S}$. cerevisiae double mutation leu2-3 leu2-112, is (ii) located on chromosome III, and (iii) has a restriction map different from that of the S. cerevisiae $L E U 2$ gene. (iv) The 0.9 $\mathrm{kb}$ EcoRI-Sall part of the fragment does not hybridize to the $\mathrm{S}$. cerevisiae $L E U 2$ sequence under high stringency conditions where it exhibits strong hybridization to similar sequences in type strains of S. bayanus, S. carlsbergensis, S. monacensis and $\mathrm{S}$. uvarum.

\section{MATERIALS AND METHODS}

\subsection{Strains and growth media}

The yeast strains used in this study are shown in Table I. As donor for the genomic library the Carlsberg lager strain 244 (syn. BK2246) was used, while the leu 2 double mutant strains of S. cerevisiae IVPX 5-2B (26) and DBY746 are the recipient for the selection of the chimeric plasmid containing the $L E U 2$ region. The other yeast strains shown in Table I have been used for comparative analyses of the cloned $L E U 2$ insert. Yeast was maintained and grown on complex medium plates (YPD (28)) at room temperature.

E. coli HB101 (recA hsd 5) was used as the host strain in bacterial transformation experiments and for the subsequent preparation of plasmid DNA. The bacteria were grown at $37^{\circ} \mathrm{C}$ in LB medium. Ampicillin $\left(50 \mu \mathrm{g} \cdot \mathrm{ml}^{-1}\right)$ or tetracycline $\left(15 \mu \mathrm{g} \cdot \mathrm{ml}^{-1}\right)$ were added as required for selection of transformants (17).

\subsection{Cloning vectors and subcloning of $L E U 2$}

The cloning vector, kindly provided by $\mathrm{M}$. MCDONELL, was the yeast - E. coli chimeric vector YRp17. YRp17 and the vector pUC13 were used for subcloning of the LEU2 inserts. Construction of the yeast genomic library from lager strain 244 and transformation of $\mathrm{Li}^{+}$treated $\mathrm{S}$. cerevisiae cells by recombinant plasmid DNA preparations were done as previously described $(7,14)$. Clones which had taken up recombinant plasmids were first isolated on plates of SC minus uracil (28). Upon replica plating to SC minus uracil and leucine (28), clones with plasmids containing a $L E U 2$ gene were identified by complementation of the leu 2 double mutation.

Plasmid DNA from a yeast transformant demonstrating simultaneous mitotic instability for uracil and leucine independence was isolated, amplified in E. coli HB101 and purified through $\mathrm{CsCl}$ centrifugation for subsequent characterization. The plasmid pC 512 (13) contains the Sall-SalI $2.3 \mathrm{~kb} L E U 2$ fragment from S. cerevisiae (29). The $0.9 \mathrm{~kb}$ EcoRI-SalI fragment with the down stream end of the $S$. cerevisiae $L E U 2$ gene (2) was eluted from a $0.7 \%$ $(w / v)$ agarose gel (32) and used as probe or subcloned into the pUC13 vector.

\subsection{Preparation of DNA, electrophoretic separation of DNA molecules and hybridization analysis}

Plasmid DNA preparations, nick translations, Southern transfers and hybridization conditions for restriction endonuclease analysis were per- 
Table I. Characteristics of Saccharomyces strains used in comparative and cloning analyses. $L E U 2$ : Diagnostic SalI fragment according to $(21,22)$.

\begin{tabular}{|c|c|c|}
\hline Strain & Genotype/LEU2 & Source \\
\hline \multicolumn{3}{|l|}{ Bottom fermenting strains: } \\
\hline \multicolumn{3}{|l|}{ S. carlsbergensis: } \\
\hline \multicolumn{3}{|l|}{$\begin{array}{l}\text { Type strain: Bottom fermenting } \\
\text { strain No. I }\end{array}$} \\
\hline C84-AJL248 & III + IV & Alfred Jørgensen Laboratories \\
\hline CBS1513 & III + IV & Centraalbureau voor Schimmelcultures \\
\hline \multicolumn{3}{|l|}{ Lager strains: } \\
\hline BK1101 Pschorr lager strain & III + IV & Carlsberg Research Center \\
\hline BK2208 Danish lager strain & III + IV & Carlsberg Research Center \\
\hline BK2224 Tuborg lager strain & III + IV & Tuborg \\
\hline $\begin{array}{l}244 \text { syn. BK } 2246 \text { Carlsberg } \\
\text { lager strain }\end{array}$ & $\begin{array}{l}L E U \text { donor strain: } \\
\text { III + IV }\end{array}$ & Carlsberg \\
\hline \multicolumn{3}{|l|}{ S. monacensis: } \\
\hline \multicolumn{3}{|l|}{$\begin{array}{l}\text { Type strain: Bottom fermenting } \\
\text { strain No. II }\end{array}$} \\
\hline CBSI 1503 & IV & Centraalbureau voor Schimmelcultures \\
\hline \multicolumn{3}{|l|}{ Other Saccharomyces species: } \\
\hline S. bayanus NCYC374 & IV & National Collection of Yeast Culture \\
\hline S. uvarum CBS395 & IV & P. PHILIPPSEN \\
\hline S. uvarum C81-1511 & IV & P. PhilipPSEN \\
\hline \multicolumn{3}{|l|}{ S. cerevisiae } \\
\hline $\mathrm{S} 288 \mathrm{C}$ & SUC2 CUPI gal2 & \\
\hline DBY746 & $\begin{array}{l}\text { leu2-3, leu2-112 MATa } \\
\text { his3 } \Delta 1 \text { ura 3-52 trpl-289 }\end{array}$ & \\
\hline K5-5A & $\begin{array}{l}\text { his4-15 LEU2 MATa } \\
\text { ade2-1 canl karl-1 }\end{array}$ & CONDE \& FinK (10) \\
\hline IVPX5-2B & $\begin{array}{l}L E U 2 \text { recipient strain: } \\
M A T \alpha \text { leu2-3 leu2-112 } \\
\text { ura3-52 ilv3-12 }\end{array}$ & J. Polaina (26) \\
\hline \multicolumn{3}{|c|}{$\begin{array}{l}\text { Chromosome transfer strains } \\
\text { (donor: BK2208, recipient: K5-5A) }\end{array}$} \\
\hline $\begin{array}{l}\text { Chromosome III substitution st } \\
\text { CYT-MSP-2208-2 }\end{array}$ & $\begin{array}{l}\text { HIS4 LEU2 MATa } \\
\text { THR4 canl ade2-1 }\end{array}$ & Pedersen (23) \\
\hline $\begin{array}{l}\text { Chromosome III addition strain } \\
\text { CYT-MSP-2208-7 }\end{array}$ & $\begin{array}{l}\text { HIS4 LEU2 MATa/ } \alpha \\
\text { THR4 canl ade2-I }\end{array}$ & Pedersen (23) \\
\hline \multicolumn{3}{|c|}{$\begin{array}{l}\text { Chromosome transfer strain } \\
\text { (donor } 244 \text { (syn. BK2246) recipient: K5-5A) }\end{array}$} \\
\hline $\mathrm{C} 80-1253$ & $\begin{array}{l}\text { HIS4 LEU2 MATa } \\
\text { THR4 canl ade2-1 }\end{array}$ & NILSSON-TILLGREN et al. (18) \\
\hline
\end{tabular}


formed as described earlier $(7,17,22)$. Protocols for yeast genomic DNA isolations and full length chromosomal DNA preparations (a modification of the SCHWARTZ and CANTOR protocol (27)) have also previously been described (23).

Electrophoretic separation of the chromosome size DNA molecules was done by orthogonal field alternation gel electrophoresis (OFAGE) (4, 5) and field inversion gel electrophoresis (FIGE) (6). The electrophoresis conditions for FIGE separations were as follows: $1 \%$ agarose in $0.5 \times \mathrm{TBE}, 80$ Volts at $22^{\circ} \mathrm{C}$. The electrophoresis period was 67 hours with a linear increasing pulse ramp starting at $t_{0 \mathrm{~h}}$ with 9 seconds forward (cathode at side of application) and 3 seconds backwards (anode at side of application). At $t_{67 \mathrm{~h}}$ the forward pulse amounted to 195 seconds and the backwards pulse to 65 seconds.

In order to obtain a binding efficiency with sulfonated probes, which is comparable to that of ${ }^{32}$ P-labelled probes, hybridizations of Southern blots after FIGE separations were done in higher salt solutions $(6 \times \mathrm{SSC})$ than previously used with gels after OFAGE $(3 \times$ SSC $)(23)$. Washes for low stringency conditions with sulfonated hybridizations probes were in $6 \times \mathrm{SSC}, 0.2 \% \mathrm{SDS}$ at $58{ }^{\circ} \mathrm{C}$, medium stringency filter washes were done in $3 \times \mathrm{SSC}, 0.2 \% \mathrm{SDS}$ at $58^{\circ} \mathrm{C}$, while high stringency filter washes were done in $1 \times \mathrm{SSC}$, $0.2 \%$ SDS at $58^{\circ} \mathrm{C}$. Autoradiographic exposures ranged from 12 hours to 3 days at $-80^{\circ} \mathrm{C}$ using Kodak X-Omatic intensifying screens on Kodak XAR5 X-ray films, while the non-radioactive detection of sulfonated probes on nitrocellulose membranes was made with the CHEMIPROBE (FMC-LITEX) and SULFOPROBE (SIGMA) systems. In both systems the cytosine groups are sulfonated by the method of SVERDLOV et al. (30). The modified cytosines are recognized by the primary antibody, which is subsequently made visible with a secondary antibody alkaline phosphatase complex. As suggested by LEBACQ et al. (16) and the manual of the CHEMIPRO$\mathrm{BE}$ system, the sulfonated probes were used in high concentrations, i.e. in the range of 0.5-2 $\mu \mathrm{g} \cdot \mathrm{ml}^{-1}$ and in a total volume of $20-25 \mathrm{ml}$ in a plastic bag. Radioactively labelled probes were used at a concentration in the range of 4-10 $\mathrm{ng} \cdot \mathrm{ml}^{-1}$ in a total volume of $100-200 \mathrm{ml}$ in a plastic tray. Antibody concentrations and block- ing solutions were used as prescribed by the CHEMIPROBE protocol, while all washings of filters after the primary and secondary antibody reactions were done in $0.5 \mathrm{M}-\mathrm{NaCl}, 0.3 \%$ Brij 35 (16).

\section{4. $L E U 2$ probes}

Four different $L E U 2$ probes were used during the course of this study: (i) the $0.9 \mathrm{~kb}$ EcoRI-SalI 3' fragment of $L E U 2$ from the S. cerevisiae SalI-SalI insert in the vector pC512(13). (ii) The pKh 1-1 plasmid containing the original Sau3AI generated $\mathrm{LEU}^{+}$insert from the $\mathrm{S}$. carlsbergensis genomic library, (iii) the $2.8 \mathrm{~kb}$ Sall-Sall $L E U 2$ containing fragment from the plasmid $\mathrm{pKh} 2-1$ (cf. Figure 1), (iv) the $0.9 \mathrm{~kb}$ EcoRI-Sall fragment from pKh2-1 after subcloning in pUC13.

\section{RESULTS}

\subsection{Restriction endonuclease site analysis of the cloned $L E U 2$ allele}

Saccharomyces cerevisiae IVPX5-2B (leu2-3, leu2-112) was transformed with $10 \mu \mathrm{g}$ of recombinant plasmid DNA from each of four pools of the $\mathrm{S}$. carlsbergensis genomic library as described by CASEY (7). Of the 3000-4000 Ura ${ }^{+}$ transformants arising from each of the pools on plates of SC minus uracil, one clone was able to grow on plates of SC minus uracil minus leucine. After verification that the $\mathrm{Ura}^{+} \mathrm{Leu}^{+}$ phenotype was unstable when grown on SC medium, the plasmid designated pKh1-1 was analysed by restriction endonuclease mapping.

Identification of the LEU2 containing sequences with in the $5.65 \mathrm{~kb}$ insert in $\mathrm{pKh} 1-1$ was done by hybridization of the $0.9 \mathrm{~kb}$ EcoRI-SalI LEU2 fragment from pC512 to a Southern blot of EcoRI digested, Sall digested and EcoRI + Sall digested plasmid. Three fragments from pKh1-1 hybridized to the EcoRI-Sall probe, namely: a $1.2 \mathrm{~kb}$ EcoRI fragment, a $2.8 \mathrm{~kb}$ Sall fragment and an $0.9 \mathrm{~kb}$ EcoRI-SalI fragment. Subsequently, it was found that the $2.8 \mathrm{~kb}$ SalI-Sall fragment in this plasmid, when subcloned in YRp 17, retained the ability to complement the leu 2 mutations in S. cerevisiae IVPX52B and DBY746. This plasmid, designated pKh2-1, contains an insert of $2.6 \mathrm{~kb}$. If DBY746 

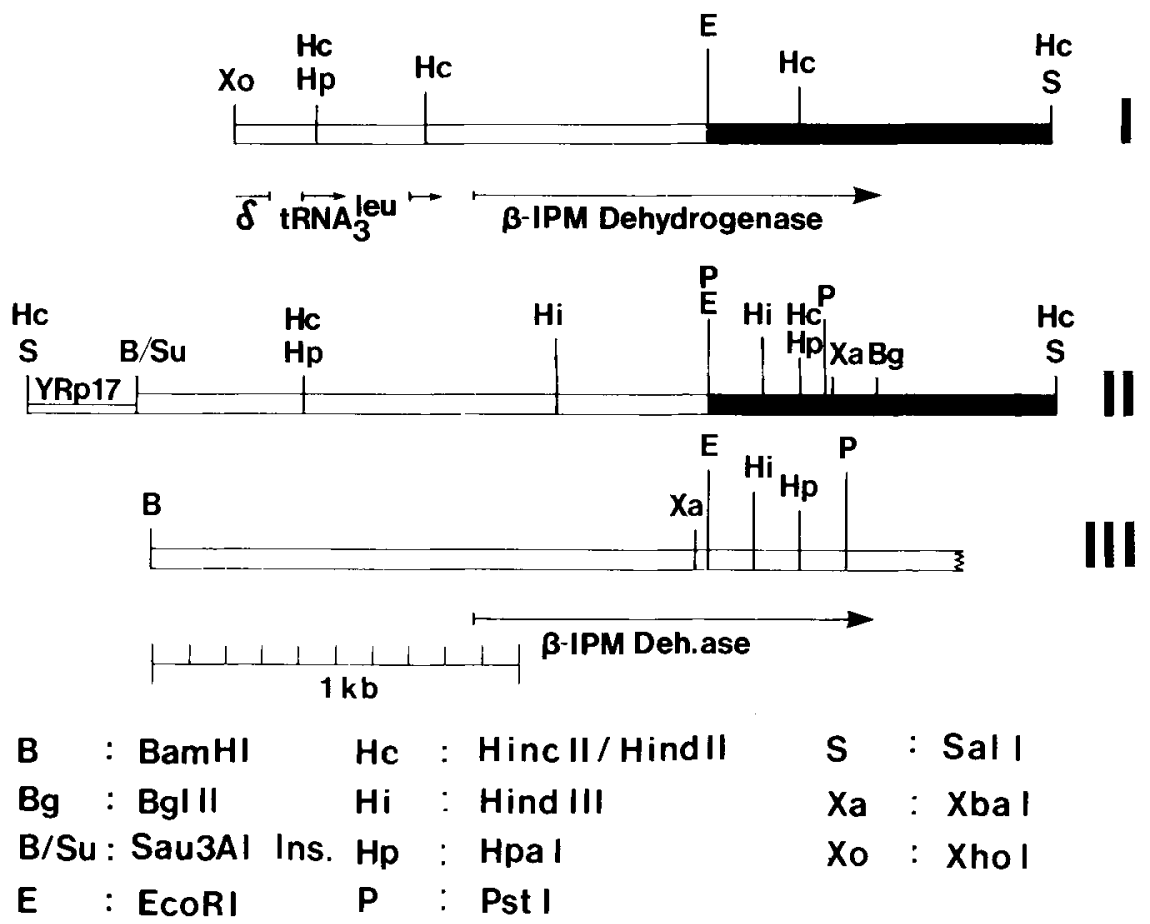

Figure 1. Restriction site maps of three $L E U 2$ genes. I) XhoI-Sall $L E U 2$ restriction endonuclease fragment from S. cerevisiae (1, 2), II) Sall-Sall $L E U 2$ fragment from lager strain 244. III) Part of BamHI-Xhol Candida maltosa LEU 2 fragment (31). The restriction endonuclease sites in I) and III) are based on the published sequences. Filled areas in I) and II) correspond to the subcloned EcoRI-Sall fragments, respectively, designated as the $0.9 \mathrm{~kb}$ EcoRI-Sall fragments from S. cerevisiae and S. carlsbergensis.

transformed with pKh2-1 is plated on SC minus uracil (non-selective conditions for leucine) instead of SC minus leucine or SC minus leucine minus uracil, several $U R A^{+} L E U^{-}$colonies are found among the transformants. The instability for the $L E U^{+}$phenotype is presumably due to the duplication of the BamHI-Sall region of the E. coli tetracycline gene in $\mathrm{pKh} 2-1$. The duplication might induce a cross-over event which loops out the $L E U 2$ gene. When the $2.6 \mathrm{~kb}$ insert was hybridized to Southern blots of digests of genomic DNA preparations from S. carlsbergensis 244 and S. cerevisiae S288C, cross hybridization to a variety of fragments was seen in both strains, indicating the presence of repeated DNA sequences. Such repeated sequences have been found upstream of the S. cerevisiae $L E U 2$ gene (tRNA and $\delta$-sequences $(1,2,11)$ ). To avoid cross hybridization of unwanted se- quences, the $0.9 \mathrm{~kb}$ EcoRI-SalI fragment from pKh2-1 was chosen as probe.

The Sall-SalI fragment was mapped for restriction sites with the endonucleases listed in Figure 1. The resulting map of the cloned carlsbergensis $L E U 2$ gene reveals six restrictions sites in the coding region which are absent in the sequenced S. cerevisiae $L E U 2$ gene $(1,2)$. Additional restriction site polymorphisms are found in the adjacent region.

\subsection{Identification of the cloned $L E U 2$ allele}

Genomic DNA from the Carlsberg lager strain 244 and S. cerevisiae (S288C) were cut with seven restriction endonucleases and the fragments separated on two gels under identical conditions and blotted onto filters. One filter was hybridized first at non-stringent conditions 
HindIII EcoRI XhoI BgIII PstI XbaI SalI BgIII PstI XbaI SalI HindIII EcoRI XhoI fragment CSCSCSCSCSCSCSCSCSCSCSCSCSCS

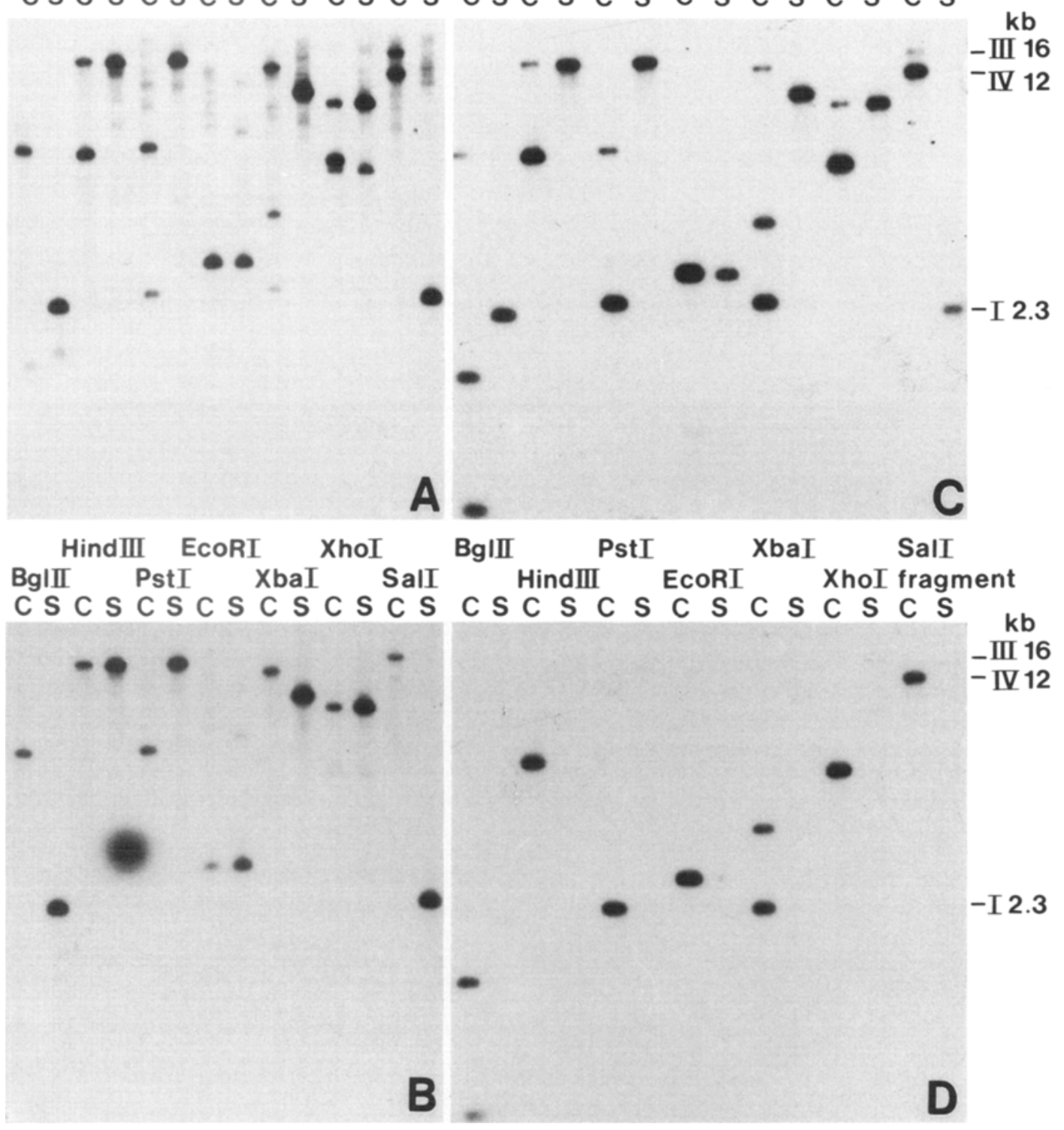

Figure 2. Molecular hybridization of endonuclease digested DNA from S. cerevisiae and lager strain 244 with the $0.9 \mathrm{~kb}{ }^{32} \mathrm{P}$-labelled EcoRI-Sall $L E U 2$ probes from S. cerevisiae S288C and lager strain 244. Panels A and B are from one filter which has been successively hybridized with the $0.9 \mathrm{~kb}$ EcoRI-SalI $L E U 2$ fragment from plasmid pC512 with an insert of S. cerevisiae at low and high stringency, while panels $C$ and $D$ are from a filter which has been hybridized successively with the $0.9 \mathrm{~kb}$ EcoRI-Sall $L E U 2$ fragment from plasmid $\mathrm{pKh} 2-1$ with an insert of the lager strain 244 at low and high stringency. Filters in panels $A$ and $C$ have been hybridized and washed at $60{ }^{\circ} \mathrm{C}$ and $3 \times S S C$, while the same two filters shown in panels $B$ and $D$ have been washed subsequently at high stringency, namely $68{ }^{\circ} \mathrm{C}$ and $0.1 \times$ SSC. Lanes containing DNA from lager strain 244 are marked with a $\mathrm{C}$ while lanes containing DNA from S. cerevisiae $\mathrm{S} 288 \mathrm{C}$ are marked with an S. 


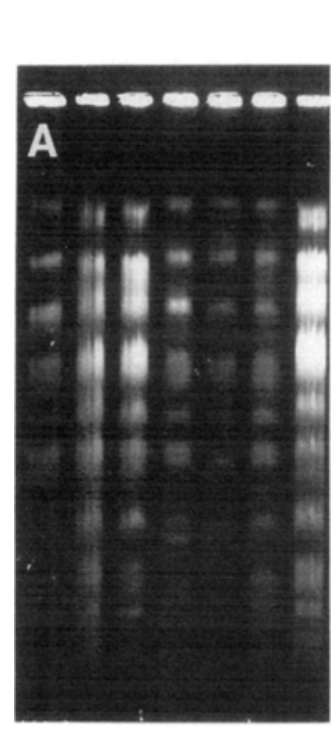

\section{Carlsbergensis probe}
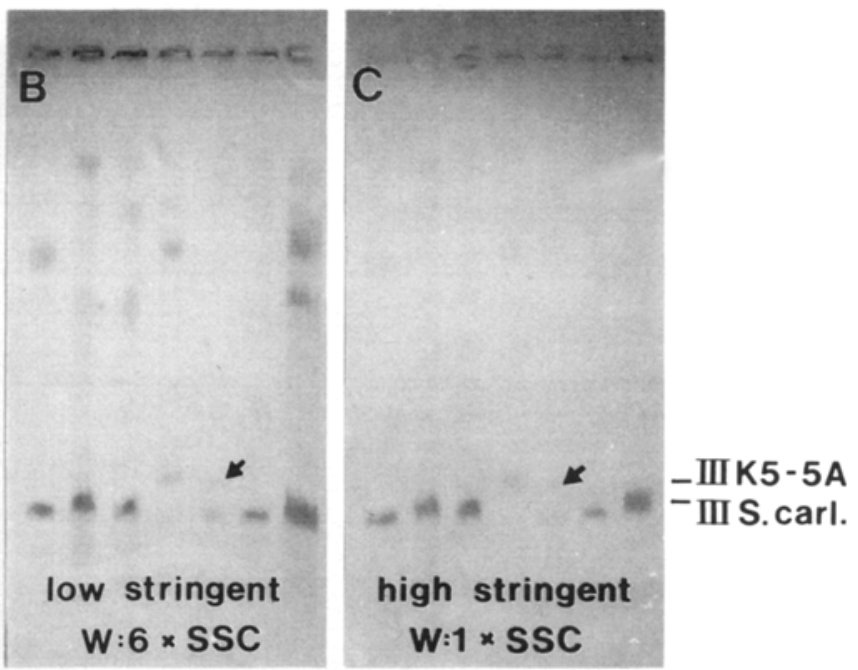

$a b c d e f g$

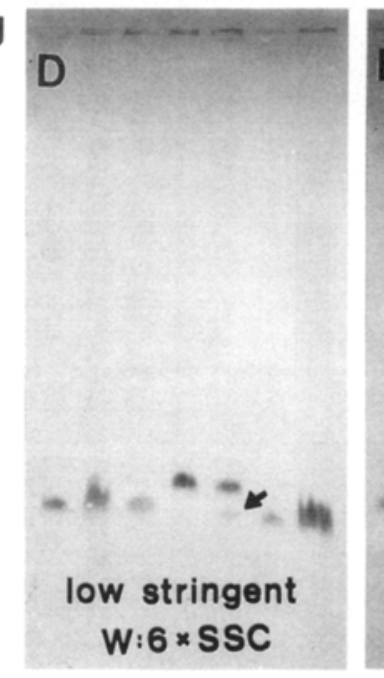

\section{FIGE}

W: Wash

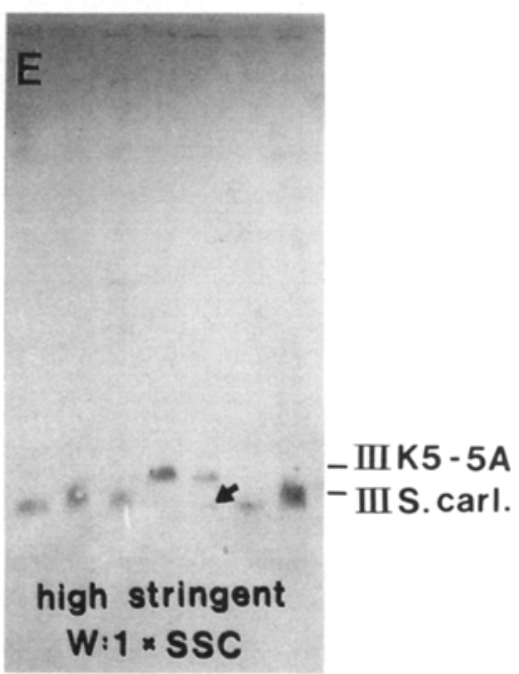

\section{Cerevisiae probe}

Figure 3. Panel A: FIGE separation of chromosomal DNA preparations from seven Saccharomyces strains. a: C80-1253 a chromosome III substitutionstrain, b: Carlsberg lager strain 244 (BK2246) donor of chromosome III in C80-1253, c: Pschorr lager BK 1101, d: K5 - 5A chromosome III receptor strain, e: CYT-MSP-2208-7, chromosome III addition strain with a chromosome III from BK2208, f: CYT-MSP-2208-2, chromosome III substitution strain with BK2208 as chromosome III donor, g: BK2208 Danish lager strain. Panels B to E: Four filters prepared from four electrophoretic separations as that depitcted in $\mathrm{A}$. The filters were hybridized to $L E U 2$ probes in $6 \times \mathrm{SSC}$ at $58^{\circ} \mathrm{C}$. Panels $\mathrm{B}$ and D: Filters were washed in $6 \times \mathrm{SSC}$ at $58^{\circ} \mathrm{C}$. Panels $\mathrm{C}$ and E: Filters washed in $1 \times \mathrm{SSC}$ at $58^{\circ} \mathrm{C}$. Filters in panels $B$ and $C$ have been hybridized with the sulfonated $0.9 \mathrm{~kb}$ EcoRI-Sall $\mathrm{S}$. carlsbergensis LEU2 probe, while the filters depicted in panels $\mathrm{D}$ and $\mathrm{E}$ were hybridized with the corresponding sulfonated $\mathrm{S}$. cerevisiae probe. Panels B to E: Black arrows point at weakly hybridizing bands. 

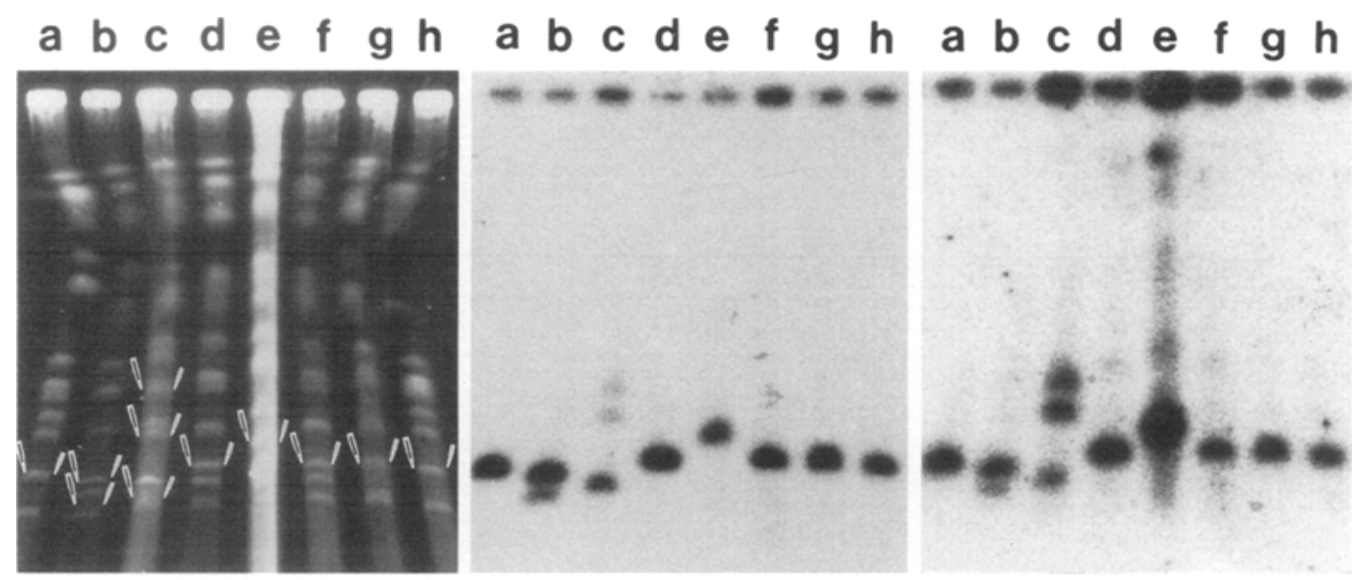

OFAGE

\section{Carlsbergensis probe Cerevisiae probe}
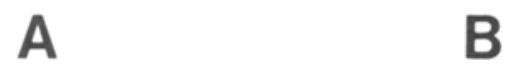

Figure 4. Panel A: OFAGE separations of chromosomal DNA preparations from 8 Saccharomyces strains. Lane a: S. uvarum CBS395, lane b: S. monacensis CBS1503, lane c: S. carlsbergensis C84-AJL248, lane d: S. carlsbergensis Carlsberg lager strain 244 (syn. BK2246), lane e: S. cerevisiae laboratory strain S288C, lane f: S. carlsbergensis Pschorr lager strain BK1 101, lane g: S. bayanus NCYC374 and lane h: S. uvarum C81-1511. Black arrow heads on the left hand side of lanes correspond to HIS4 hybridizing bands (23) and white arrow heads on the right hand side of the lanes correspond to the $L E U 2$ hybridizing bands visualized in panels $\mathrm{B}$ and $\mathrm{C}$. Panels $B$ and $C$ : Two hybridizations of the Southern blot from the gel in panel A. The chromosomal DNA blot has been hybridized with either the ${ }^{32} \mathrm{P}$-labelled $0.9 \mathrm{~kb}$ EcoRI-Sall $L E U 2$ fragment from Carlsberg lager strain 244 (panel B) or with the $0.9 \mathrm{~kb}$ EcoRI-Sall $L E U 2$ fragment from S. cerevisiae (panel C). The filter has been hybridized and later washed at $60^{\circ} \mathrm{C}$ and $3 \times \mathrm{SSC}$ in both cases. The lettering of the strains corresponds to panel $\mathrm{A}$.

and subsequently at stringent conditions to the $0.9 \mathrm{~kb}{ }^{32} \mathrm{P}$-labelled EcoRI-SalI 3' LEU2 fragment of S. cerevisiae (Figure $2 \mathrm{~A}$ and $\mathrm{B}$ ). The filter of the other gel was hybridized in the same way to the corresponding $L E U 2$ fragment from $\mathrm{S}$. carlsbergensis (Figure $2 \mathrm{C}$ and $\mathrm{D}$ ). The comparison reveals that the lager strain 244 contains at least two $L E U 2$ genes: One $L E U 2$ allele which is diagnosed with the aid of SalI fragment III gives with HindIII, EcoRI and XhoI digestions the same restriction fragment patterns as the LEU2 allele from S. cerevisiae S288C (Figure 2B). The other $L E U 2$ allele which is diagnosed with the aid of SalI fragment IV gives under stringent conditions with the carlsbergensis probe rise to unique restriction fragment patterns with the endonucleases tested (Figure 2D).

In Figures $2 \mathrm{~A}$ and $2 \mathrm{C}$ are compared autoradiographs of the filters hybridized with the S. cerevisiae $0.9 \mathrm{~kb}$ EcoRI-SalI $L E U 2$ fragment from the vector pC512 (Figure 2A) and the 0.9 $\mathrm{kb}$ EcoRI-SalI $L E U 2$ fragment cloned from the Carlsberg lager strain and subcloned into pUC13 (Figure 2C). The hybridization and washing conditions for low stringency were both times $3 \times \mathrm{SSC}$ at $60^{\circ} \mathrm{C}$. The two autoradiographs yielded the same restriction fragment patterns but fragments hybridising weakly with the cerevisiae derived probe hybridize strongly with other and vice versa. Complementary restriction fragment patterns are obtained at high stringency hybridization conditions (Figures 2B and 2D).

In previous genetic and molecular studies it was found that the carlsbergensis specific LEU2 and HIS4 alleles were linked and located on a chromosome III which in orthogonal field alternation gel electrophoresis (OFAGE) moves 
faster than the corresponding chromosome III from S. cerevisiae $(23,24)$. To demonstrate that the cloned $L E U 2$ gene from $\mathrm{S}$. carlsbergensis originates from the faster migrating (shorter) chromosome III, the $0.9 \mathrm{~kb}$ EcoRI-Sall fragments from $\mathrm{S}$. cerevisiae and $\mathrm{S}$. carlsbergensis LEU2 were hybridized to Southern blots of chromosome III addition and substitution strains. The ethidium bromide stained gel depicted in Figure 3A contains chromosomal DNA from seven Saccharomyces strains separated by the FIGE system. Three additional gels with the same DNA samples have been prepared and all four were then blotted on filters. Hybridizations with the two $L E U 2$ probes were done under stringent (Figure $3 \mathrm{C}$ and $\mathrm{E}$ ) and less stringent conditions (Figure $3 \mathrm{~B}$ and $\mathrm{D}$ ). The detection of LEU2 containing chromosomal bands has been done by antibody recognition of sulfonated probes. Filters in Figure 3, panels B and $\mathrm{C}$ were hybridized with pUC13 containing the $\mathrm{S}$. carlsbergensis $0.9 \mathrm{~kb}$ EcoRI-Sall insert, while the filters depicted in panels $D$ and $E$ were hybridized with the corresponding S. cerevisiae probe.

At low stringency washes both probes detect the chromosomes III in all strains, but with preferential hybridization to chromosomes carrying similar or identical $L E U 2$ alleles. This differential effect is pronounced in the chromosome III addition strain CYT-MSP-2208-7 (strain e), where the $\mathrm{S}$. carlsbergensis LEU2 probe shows stronger binding to the faster moving chromosome III (panel B), while the S. cerevisiae $L E U 2$ probe binds preferentially to the slower moving chromosome III originating from K5-5A (panel D). At high stringency washes the preferential hybridization of the probes is similar (panels $\mathrm{C}$ and $\mathrm{E}$ ). To confirm that the cloned $L E U 2$ gene is located on similarly sized chromosomes III in other Saccharomyces species the $0.9 \mathrm{~kb}$ EcoRI-SalI fragments subcloned from $\mathrm{pC} 512$ and $\mathrm{pKh} 2-1$ were hybridized to the Southern blot of the OFAGE gel shown in Figure 4. In panel $\mathrm{A}$, bands hybridizing to the HIS4 probe (pC503 (12)) are indicated by black arrow heads (left side of lanes) and LEU2 hybridizing bands indicated by white arrow heads (right side of lanes). In all strains the HIS4 and $L E U 2$ hybridizing bands coincide and thus the bands contain chromosome III or at least the part of chromosome III which corresponds to the left arm of chromosome III in S. cerevisiae. It should be mentioned that $\mathrm{S}$. monacensis CBS1 503 contains two chromosomal bands hybridizing with $L E U 2$ and S. carlsbergensis C84AJL248 contains three. The slower chromosomal band hybridizing with LEU2 in S. monacensis has a size and hybridization intensity similar to such a chromosome in the lager strains, while the shorter chromosomal band is of a size and a hybridization intensity similar to the shortest of the three with $L E U 2$ hybridizing chromosomal bands in S. carlsbergensis C84AJL248.

\section{DISCUSSION}

The present investigation has shown the existence of one functional $L E U 2$ gene in S. carlsbergensis, which contains unique restriction sites compared to the corresponding gene from S. cerevisiae.

The cloned fragment exhibits restriction site similarities to the $L E U 2$ gene from Candida maltosa (31) (Figure 1), even though C. maltosa seems not closely related to the $\mathrm{S}$. cerevisiae group. The Mol\% of $\mathrm{G}+\mathrm{C}$ of nuclear DNA from C. maltosa is in the range $35.6-37.3$ while the $\mathrm{Mol} \% \mathrm{G}+\mathrm{C}$ of the $\mathrm{S}$. cerevisiae group is in the range of 38.8-42.0 (3).

Chromosomal diversity is observed among the strains of Saccharomyces when probed with sequences from the two $L E U 2$ alleles. For example, while the Pschorr lager strain is homozygous for the HIS4 pattern II allele (20) and heterozygous for the two $L E U 2$ alleles (22), the S. monacensis strain is homozygous for HIS4 pattern II as well as the carlsbergensis specific LEU2 allele with the diagnostic Sall fragment IV (22). Of potentially evolutionary significance is the observation that S. bayanus and S. monacensis yeasts possess a chromosome III with the same size and the carlsbergensis specific $L E U 2$ allele, as found in Carlsberg lager strain 244.

The most distinct diversity in size of chromosome III was found in type strains of S. carlsbergensis (e.g. C84-AJL248). The strain was found to be trisomic for chromosome III (or at least containing three chromosomes III left arms) 
with all three chromosomes migrating differently of chromosome III from other lager strains. The two longer chromosomes III contained both a S. cerevisiae type of $L E U 2$ (judged by the preferential hybridization), while the short chromosome contained the carlsbergensis specific $L E U 2$ allele. It has previously been found (23) that the two longer chromosomes also show preferential hybridization to HIS4 from S. cerevisiae (cf. also Figure 4).

Interestingly, the $\mathrm{S}$. monacensis type strain CBS1503 might well be trisomic for chromosome III, containing only the carlsbergensis specific alleles for $L E U 2$ and HIS4 . Both chromosomal bands show preferential hybridization to the carlsbergensis specific alleles and the slower migrating band hybridizes with an intensity twice as strong as the faster moving band (Figure 4). This indicates that the slower moving band contains two copies of chromosome III.

\section{ACKNOWLEDGEMENTS}

The authors would like to thank Dr. M. MCDONELl and Lic.scient. S. HolmbERG for their kind donation of plasmids, YRp17 and pC512, used in this study, Prof. M.C. KIELlandBRANDT and Prof. D. von WETTSTEIN for critical reading of the manuscript. We express our great appriciation to Ms. G. BANK and Ms. S. BRUUN for skilful technical assistance during the course of this study, Ms. A. ABEL and N. RASMUSSEN for figure preparation, Ms. H. THEM NIELSEN and Ms. L. TRILLOT for typing the manuscript.

\section{REFERENCES}

1. Andreadis, A., Y.-P. Hsu, G.B. Kohlhaw \& P. SCHIMmel: Nucleotide sequence of yeast $L E U 2$ shows 5 '-noncoding region has sequences cognate to leucine Cell 31, 319-325 (1982)

2. Andreadis, A., Y.P. Hsu, M. Hermodson, G. KoHLhaw \& P. SCHIMMEL: Yeast LEU2. Repression of mRNA levels by leucine and primary structure of the gene product. J. Biol. Chem. 259, 8059-8062 (1984)

3. Barnett, J.A., R.W. PaYne \& D. Yarrow: Yeasts: Characteristics and identification. Cambridge University Press (1983)

4. CARLE, G.F. \& M.V. Olson: Separation of chromosomal DNA molecules from yeast by orthogonal- field alternation gel electrophoresis. Nucl. Acid Res. 12, 5647-5664 (1984)

5. CARLE, G.F. \& M.V. Olson: An electrophoretic karyotype for yeast. Proc. Natl. Acad. Sci. USA 82, 3756-3760 (1985)

6. Carle, G.F., M. Frank \& M.V. Olson: Electrophoretic separations of large DNA molecules by periodic inversion of the electric field. Science 232, 65-68 (1986)

7. CASEY, G.P.: Cloning and analysis of two alleles of the ILV3 gene from Saccharomyces carlsbergensis. Carlsberg Res. Commun. 51, 327-341 (1986)

8. CASEY, G.P.: Molecular and genetic analysis of chromosome $\mathrm{X}$ in Saccharomyces carlsbergensis. Carlsberg Res. Commun. 51, 343-362 (1986)

9. Chinault, A.C. \& J. CARBON: Overlap hybridization screening: Isolation and characterization of overlapping DNA fragments surrounding the LEU2 gene on yeast chromosome III. Gene 5, 111-126 (1979)

10. CONDE, J. \& G.R. FINK: A mutant of Saccharomyces cerevisiae defective for nuclear fusion. Proc. Natl. Acad. Sci. USA 73, 3651-3655 (1976)

11. Dobson, M.J., S.M. Kingsman \& A.J. Kingsman: Sequence variation in the LEU2 region of the Saccharomyces cerevisiae genome. Gene 16, 133 139 (1981)

12. Holmberg, S., J.G.L. Petersen, T. Nilsson-TillGREN \& M.C. KIELLAND-BRANDT: Molecular characterization of a Saccharomyces plasmid containing the HIS4 gene. Carlsberg Res. Commun. 44, 269-282 (1979)

13. Holmberg, S.: Genetic differences between Saccharomyces carlsbergensis and S. cerevisiae II. Restriction endonuclease analysis of genes in chromosome III. Carlsberg Res. Commun. 47, 233-244 (1982)

14. Ito, H., Y. Fukuda, K Murata \& A. Kimura: Transformation of intact yeast cells treated with alkali kations. J. Bacteriol. 153, 163-168 (1983)

15. KEIDING, A.K.: Genetic and molecular characterization of a destiller's yeast. Carlsberg Res. Commun. 50, 95-125 (1985)

16. LebacQ, P., D. SQualli, M. Duchenne, P. PouletTY \& M. JOANNES: A new sensitive non isotopic method using sulfonated probes to detect picogram quantities of specific DNA sequences on blot hybridization. Biochem. Biophys. Metods (In press) (1987)

17. Maniatis, T., E.F. Fritsch \& J. Sambrook: Molecular cloning. A laboratory manual. Cold Spring Harbor Laboratory. Cold Spring Harbor, New York (1982)

18. Nilsson-Tillgren, T., C. GJermansen, M.C. Kielland-Brandt, J.G.L. Petersen \& S. HolmberG: 
Genetic differences between Saccharomyces carlsbergensis and $\mathrm{S}$. cerevisiae. Analysis of chromosome III by single chromosome transfer. Carlsberg Res. Commun. 46, 65-76 (1981)

19. Nilsson-Tillgren, T., C. Gjermansen, S. HolmBERG, J.G.L. PETERSEN \& M.C. KIELLAND-BRANDT: Analysis of chromosome $\mathrm{V}$ and the $I L V I$ gene from Saccharomyces carlsbergensis. Carlsberg Res. Commun. 51, 309-326 (1986)

20. Pedersen, M.B.: DNA sequence polymorphisms in the genus Saccharomyces. I. Comparison of the HIS4 and ribosomal RNA genes in lager strains, ale strains and various species. Carlsberg Res. Commun. 48, 485-503 (1983)

21. Pedersen, M.B.: DNA sequence polymorphisms in the genus Saccharomyces. II. Analysis of the genes RDNI, HIS4, LEU2 and Ty transposable elements in Carlsberg, Tuborg and 22 Bavarian brewing strains. Carlsberg Res. Commun. 50, 263-272 (1985)

22. Pedersen, M.B.: DNA sequence polymorphisms in the genus Saccharomyces. III. Restriction endonuclease fragment patterns of chromosomal regions in brewing and other yeast strains. Carlsberg Res. Commun. 51, 163-183 (1986)

23. Pedersen, M.B.: DNA sequence polymorphisms in the genus Saccharomyces. IV. Homoeologous chromosomes III of Saccharomyces bayanus, S. carlsbergensis and S. uvarum. Carlsberg Res. Commun. 51, 185-202 (1986)

24. Pedersen, M.B.: Practical use of electro-karyotypes for brewing yeast identification. Proc. 21 th Europ. Brewery Conv. Congr. Madrid, pp. 489496 (1987)

Accepted by E. LuND
25. Petersen, J.G.L., T. Nil.sson-Tillgren, M.C.Kielland-BrandT, C. GJermansen \& S. Holmberg: Structural heterozygosis at genes ILV2 and ILV5 in Saccharomyces carlsbergensis. Curr. Genet. 12,167-174 (1987)

26. Polaina, J.: Cloning of the $I L V 2, I L V 3$ and $I L V 5$ genes of Saccharomyces cerevisiae. Carlsberg Res. Commun. 49, 577-584 (1984)

27. Schwartz, D.C. \& C.R. Cantor: Separation of yeast chromosome-sized DNAs by pulsed field gradient gel electrophoresis. Cell 37, 67-75 (1984)

28. Sherman, F., G.R. FinK \& J.R. Hicks: Methods in Yeast Genetics. Cold Spring Harbor Laboratory, Cold Spring Harbor, N.Y. 1 1724, pp. 61-64 (1979)

29. Storms, R.K., J.B. McNiel, P.S. KhandeKar, G. AN, J.PAR KER \& J.D. FrIESEN: Chimeric plasmid for cloning of deoxyribonucleic acid sequences in Saccharomyces cerevisiae. J. Bacteriol. 140, 73-82 (1979)

30. Sverdlov, E.D., G.S. Monastyrskaya, L.I. Guskova, T.L. LeVitan, V.I. SheIchenko \& E.I. BODOWSKY: Modification of cytidine residues with a bisulfite-O-methylhydroxylamine mixture. Biochim. et Biophys. Acta 340, 153-165 (1974)

31. TaKagi, M., N. Kobayashi, M. Sugimoto, T. Fujil, J. WATARI \& K. YANO: Nucleotide sequencing analysis of a LEU gene of Candida maltosa which complements leuB mutation of Escherichia coli and leu2 mutation of Saccharomyces cerevisiae. Curr. Genet. 11, 451-457 (1987)

32. YANG, R.C.A.,J.LIS\&R. WU: Elution of DNA from agarose gels after electrophoresis: In: Methods in Enzymology, R.Wu, ed. Academic Press, New York, 68, pp. 179-182 (1979) 